\title{
ANALISIS MOTIF ANYAMAN DAN AKTIVITAS FUNDAMENTAL MATEMATIS DALAM SENI MENGANYAM DI DESA PLAOSAN KABUPATEN KEDIRI
}

\author{
Nur Fadilatul Ilmiyah, Annisa', Azizatul Fitriyah, Berlyana Sukma Vebyanti \\ Institut Agama Islam Negeri Kediri \\ nur.fadilatul.ilmiyah@iainkediri.ac.id
}

\begin{abstract}
:
Mathematical contextualization is interpreted as identifying the existence of mathematics developed by different cultural groups. The existence of ethnomathematics in education offers a learning approach that connects mathematics with the local cultural wisdom of the community. The main focus of this research is to identify ethnomathematics in woven handicrafts in Plaosan Village, Kediri Regency. This research is qualitative descriptive research. Data were collected using observation, documentation, interview, and literature study techniques. The results showed that there were ethnomathematics in woven handicrafts in Plaosan Village. The mathematical elements that can be found in the woven motifs are the concept of the plane, the concept of lines and the relationships between lines, the concept of angles, and the concept of transformational geometry. The fundamental mathematics activities that can be found in the weaving activities are counting, measuring, designing, locating, playing, and explaining.
\end{abstract}

Keywords: woven handicraft, fundamental mathematics activities, ethnomathematics

\section{PENDAHULUAN}

Matematika sebagai pondasi pengembangan sains dan teknologi sering kali luput dalam klaster mata pelajaran yang diminati oleh siswa. Rendahnya minat siswa terhadap matematika ditengarai oleh beberapa hal mendasar seperti konsep yang rumit dan membutuhkan waktu lama untuk dapat dipahami, instruksi yang tidak jelas, serta tidak adanya kesan yang mendalam sehingga konsep-konsep matematika tersebut mudah untuk dilupakan (Gafoor \& Kurukkan, 2015). Kognisi tentang poin-poin penting dalam pembelajaran matematika yang disampaikan oleh guru di sekolah belum sepenuhnya mengakomodir seluruh aspek yang mungkin (Soedjadi, 2007). Pembelajaran yang ada saat ini masih mengutamakan penguasaan konsep daripada kecakapan dalam menguraikan kaitan-kaitan yang bermakna antara matematika dengan lingkungan di sekitar siswa (Anggraena, 2019).

Dalam tempo waktu yang cukup lama, matematika dianggap sebagai bidang keilmuan yang bias dan tidak ada kaitannya dengan budaya serta nilai-nilai sosial (Rosa \& Orey, 2011). Padahal dalam kondisi konkretnya, setiap proses pembelajaran tidak bisa berlangsung secara abstrak dan bebas konteks, artinya proses belajar matematika pun tidak sepenuhnya terbebas dari pengaruh sosial. Lanskap berpikir seorang siswa dalam mempelajari dan memahami sesuatu dipengaruhi salah satunya oleh perkembangan budaya masyarakatnya (Wahyuni 
et al., 2013). Hal ini dapat terjadi karena siswa terlibat langsung dan memiliki peran dalam budaya tersebut.

Budaya dipenuhi oleh artefak-artefak yang kaya akan konsep matematis sehingga dapat dikonklusikan bahwa matematika adalah komponen yang terintegrasi dengan konteks budaya (d'Entremont, 2015). Konstektualisasi matematika diinterpretasikan sebagai bentuk identifikasi pengejawantahan matematika yang dikembangkan oleh beragam kelompok budaya, sehingga dalam hal ini matematika dapat dianggap sebagai produk pengembangan budaya (Rosa \& Orey, 2011). Agar pembelajaran matematika konstektual dapat berjalan secara efektif, guru perlu menggali perihal faktor-faktor lingkungan di sekitar siswa yang kiranya mampu memberikan kesan, dampak dan pengaruh dalam proses pembelajaran matematika di dalam kelas (Ilmiyah et al., 2020).

Etnomatematika merupakan kajian tentang matematika dengan menggunakan sudut pandang budaya lokal yang pertama kali dicetuskan pada tahun 1997 oleh D'Ambrosio (Wahyuni et al., 2013). Etnomatematika mempelajari tentang cara penyampaian konsep-konsep matematis yang dapat diadaptasikan dari budaya masyarakat setempat. Tujuan dari penyajian etnomatematika di sekolah adalah untuk meningkatkan pemahaman siswa terhadap matematika sebagai objek universal dan terakulturasi, serta meningkatkan kemampuan siswa dalam menyingkap koneksi yang bermakna antara matematika dengan budaya di sekitarnya (Rosa \& Orey, 2011). Hadirnya etnomatematika patut untuk diterapkan dan dikembangkan sebagai bentuk inovasi dalam pembelajaran matematika konstektual.

Telaah etnomatematika di dalam pembelajaran matematika sekolah meliputi segala aspek kajian seperti pertanian, perdagangan, rancang bangun, ornamen, desain motif, hubungan kekerabatan, praktek spiritual dan sebagainya (Puspadewi \& Putra, 2014). Kajian etnomatematika pada unsur-unsur kebudayaan di Kediri telah banyak dilakukan, seperti kajian mengenai pola batik tenun (ATBM) khas Kota Kediri (Samijo \& Yohanie, 2017), rancang bangun dan ornamen Masjid AlKhalid Kediri (Ilmiyah et al., 2020), motif batik khas Kediri (Jannah, 2019), proses pembuatan Tahu Takwa khas Kediri (Khalimah et al., 2017), dan sebagainya. Masih banyak unsur kebudayaan lain dari Kediri yang menarik untuk dikaji dari sisi etnomatematika, salah satu diantaranya adalah motif anyaman dan aktifitas fundamental matematis yang ada dalam seni menganyam di Desa Plaosan Kabupaten Kediri. Heonigman (dalam Prabawati, 2016) menyatakan bahwa anyaman termasuk dalam kategori artefak budaya, yaitu wujud kebudayaan fisik yang diperoleh dari aktivitas masyarakat untuk membantu kegiatan hidupnya sehari-hari.

Telah banyak penelitian tentang etnomatematika pada kerajinan anyaman. Sebagai contoh, Prabawati (2016) mencoba untuk menggali etnomatematika berupa konsep teselasi pada motif Anyaman Rajapolah Kabupaten Tasikmalaya. Resfaty, Muzdalipah, dan Hidayat (2019) menjelaskan dari hasil penelitiannya bahwa terdapat etnomatematika berupa pola barisan bilangan berulang dalam motif Anyaman Mendong Daerah Manonjaya Kabupaten Tasikamalaya. Ratuanik dan Kundre (2018) melakukan penelitian etnomatematika berupa konsep teselasi pada kerajinan tangan anyaman masyarakat Maluku Tenggara Barat serta pemanfaatannya dalam pembelajaran. Puspadewi dan Putra (2014) melakukan 
penelitian tentang etnomatematika pada kerajinan Anyaman Bali. Hasil dari penelitiannya ini menjelaskan bahwa terdapat unsur matematika di dalam kerajinan Anyaman Bali meliputi konsep teselasi, bangun datar, kesimetrisan, sudut, serta hubungan antar garis.

Penelitian ini dilakukan untuk mengidentifikasi keberadaan etnomatematika pada seni menganyam di Desa Plaosan Kabupaten Kediri. Proses identifikasi dilakukan dengan menggali dan menganalisis unsur-unsur matematis yang dapat ditemukan dalam motif anyaman. Sebagai bentuk kebaruan dari penelitianpenelitian sebelumnya, akan dikaji pula eksistensi dari aktifitas fundamental matematis dalam kegiatan menganyam di Desa Plaosan. Analisis aktifitas fundamental matematis ini dilakukan dengan mengacu pada klasifikasi Bishop. Penelitian ini diharapkan mampu mengungkap dan mendeskripsikan bentuk etnomatematika yang ada dalam kerajinan anyaman Desa Plaosan. Selanjutnya hasil penelitian dapat dimanfaatkan dalam rangka pengembangan pembelajaran matematika konstektual yang bermakna dan menyenangkan dengan berbasis budaya lokal Kediri.

\section{METODE PENELITIAN}

Ragam penelitian yang diusung dalam artikel ini adalah penelitian kualitatif dengan titik fokus pembahasan pada unsur-unsur matematika serta aktifitas fundamental matematis yang dapat ditemukan dalam kerajinan anyaman di Desa Plaosan Kabupaten Kediri. Dua orang pengrajin anyaman di Desa Plaosan berperan sebagai subjek penelitian. Objek penelitian difokuskan pada motif kerajinan anyaman yang diproduksi oleh pengrajin di Dusun Sumberwuluh, RT.32, RW.08, Desa Plaosan, Kecamatan Wates, Kabupaten Kediri beserta aktifitas-aktivitas matematis yang dilakukan selama proses pembuatan anyaman. Peneliti sebagai human instrument bertugas untuk menentukan titik fokus penelitian, memilih subjek penelitian, menghimpun data, memberikan penilaian pada kualitas data, melakukan analisis pada data dan menyimpulkan hasil penelitian.

Data primer dihimpun melalui teknik triangulasi dengan menggabungkan teknik observasi, wawancara dan dokumentasi. Melalui kegiatan observasi, peneliti dapat mengamati langsung produk anyaman dan proses pembuatan produk tersebut mulai dari menyiapkan peralatan dan bahan, membuat desain dan rancangan, serta tahap finishing produk sebelum dijual kepada pengepul. Dari kegiatan ini, peneliti mulai memiliki gambaran dalam memilih bagian-bagian dari produk serta aktifitas dalam menganyam yang berpotensi untuk dianalisis dan dikaji unsur-unsur matematikanya. Untuk mempertajam data dan dugaan, peneliti melakukan kegiatan wawancara pada dua orang pengrajin anyaman di Desa Plaosan. Diperoleh data-data terkait sejarah munculnya anyaman bambu di Desa Plaosan, jenis-jenis barang anyaman yang diproduksi, cara membuat anyaman beserta bahan dan peralatan yang digunakan, biaya produksi, harga jual produk, aktivitas-aktivitas fundamental matematis dalam menganyam dan sebagainya. Peneliti kemudian mendokumentasikan hasil wawancara dalam bentuk audio dan catatan tertulis, serta mengambil beberapa foto produk dan aktifitas dalam menganyam yang dianggap relevan dengan topik penelitian. Data sekunder dihimpun melalui teknik studi kepustakaan. Dari hasil studi kepustakaan diperoleh 
data-data terkait etnomatematika secara umum dan etnomatematika pada kerajinan anyaman, beberapa filosofi pada kerajinan anyaman, serta kompetensi dasar dan topik pembelajaran matematika sekolah yang relevan dengan unsur matematika dalam kerajinan anyaman di Desa Plaosan.

Setelah data terkumpul dilakukan reduksi data, penyajian data dan penarikan kesimpulan. Pada tahap reduksi data, data yang dipilih adalah data yang berkaitan dengan unsur-unsur etnomatematika pada motif anyaman dan aktifitas pembuatan anyaman. Data hasil reduksi kemudian disajikan secara deskriptif. Pada tahapan ini, dideskripsikan unsur-unsur matematis yang ada dalam motif anyaman beserta kompetensi dasar dan materi pokok yang bisa diajarkan di sekolah. Selain itu, pada tahapan ini juga dideskripsikan jenis aktifitas fundamental matematis yang dapat ditemukan dalam proses pembuatan anyaman. Dalam penelitian ini, analisis aktifitas fundamental matematis dilakukan dengan mengacu pada klasifikasi oleh Bishop. Aktifitas fundamental matematis tersebut terklasifikasikan menjadi 6 jenis kegiatan, yaitu membilang, mengukur, mendesain, menentuan letak, menjelaskan, dan bermain. Tahapan terakhir yang dilakukan oleh peneliti adalah menarik kesimpulan dengan memberikan klarifikasi berupa ada dan tidaknya etnomatematika pada motif anyaman dan kegiatan menganyam di Desa Plaosan Kabupaten Kediri.

\section{HASIL DAN PEMBAHASAN}

\section{Produk Kerajinan Anyaman Desa Plaosan}

Di Kabupaten Kediri terdapat beberapa tempat pengrajin anyaman bambu, salah satunya di Dusun Bondo, Desa Wates, Kecamatan Wates, dan di Dusun Sumberwuluh, Desa Plaosan, Kecamatan Wates. Namun, yang sampai saat ini masih aktif memproduksi anyaman adalah para pengrajin di Desa Plaosan. Lahirnya seni menganyam di Desa Plaosan merupakan inisiatif dari kepala desa di masa lampau untuk mengadakan penyuluhan tentang seni menganyam dengan mendatangkan pengrajin anyaman dari Nganjuk.

Sebagian dari warga Desa Plaosan mendirikan industri rumahan dan mengerjakan produksi anyaman saat menerima pesanan atau untuk sekadar mengisi waktu senggang. Beberapa jenis produk yang dihasilkan oleh warga Desa Plaosan antara lain, tompo yang berfungsi sebagai tempat nasi, tas, tempat tissue, pot bunga, pot gantung, besek (tompo kecil), dan sebagainya. Berbagai macam produk anyaman ini dimanfaatkan oleh warga untuk keperluan sehari-hari, souvenir pernikahan, oleh-oleh khas atau dijual kepada para pengepul dan selanjutnya didistribusikan ke daerah yang lain.

Pendapatan dari hasil produksi dalam satu hari tidak dapat diprediksikan dengan pasti, khususnya untuk produk anyaman yang berbahan utama bambu. Hal ini disebabkan karena kondisi bambu harus benar-benar kering sebelum diirat agar produk anyaman bambu tidak mudah berjamur. Di musim kemarau, pendapatan melonjak karena bahan melimpah sehingga para pengrajin dapat memproduksi anyaman dalam jumlah yang banyak. Di musim penghujan, pendapatan menjadi menyusut disebabkan jumlah produksi yang tidak maksimal dan beberapa produk anyaman ditumbuhi jamur. Untuk mengantisipasi hal tersebut, para pengrajin biasanya akan mengasapi bambu sebelum diirat. 


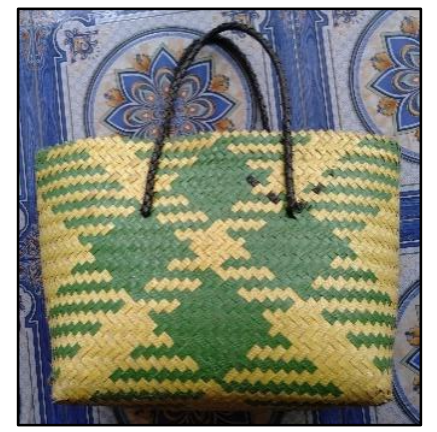

Gambar 1. Kerajinan Anyaman Tas Sumber: Dokumentasi Peneliti

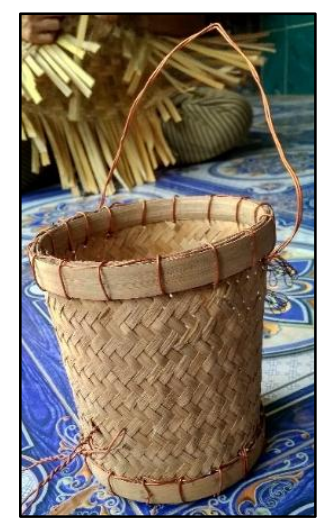

Gambar 3. Kerajinan Anyaman Pot Gantung Sumber: Dokumentasi Peneliti

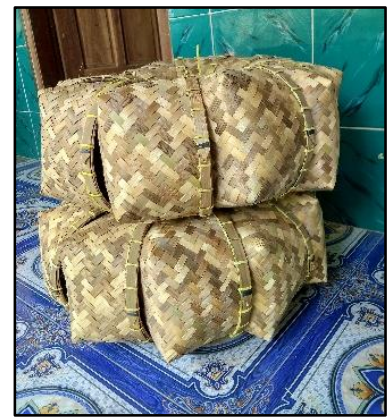

Gambar 2. Kerajinan Anyaman Tompo Sumber: Dokumentasi Peneliti

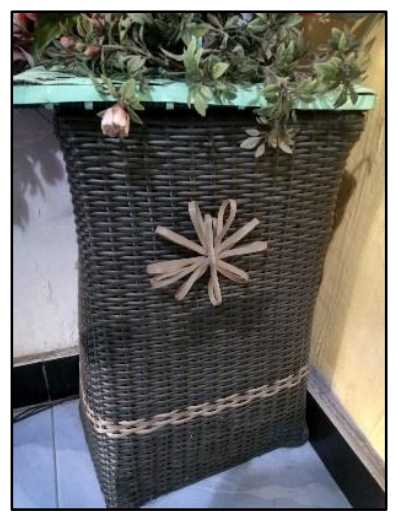

Gambar 4. Kerajinan Anyaman Pot Bunga Sumber: Dokumentasi Peneliti

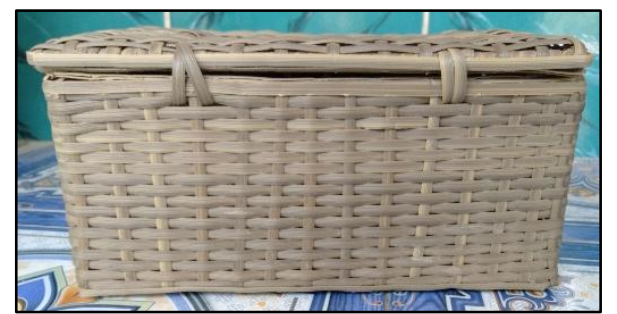

Gambar 5. Kerajinan Anyaman Tempat Tissue Sumber: Dokumentasi Peneliti

\section{Analisis Unsur-unsur Matematis dalam Motif Anyaman Produk Kerajinan Anyaman Desa Plaosan}

Secara garis besar, beberapa unsur matematika yang dapat ditemukan dalam motif anyaman dari produk kerajinan anyaman Desa Plaosan antara lain, konsep mengenai bidang datar, konsep mengenai garis dan hubungan antar garis, konsep mengenai sudut, dan konsep mengenai geometri transformasi. Tabel berikut merupakan representasi informasi yang lebih detail mengenai motif anyaman beserta unsur-unsur matematika yang dapat ditemukan di dalamnya. 
Tabel 1. Unsur-unsur Matematika dalam Motif Anyaman dari Produk Kerajinan Anyaman Desa Plaosan

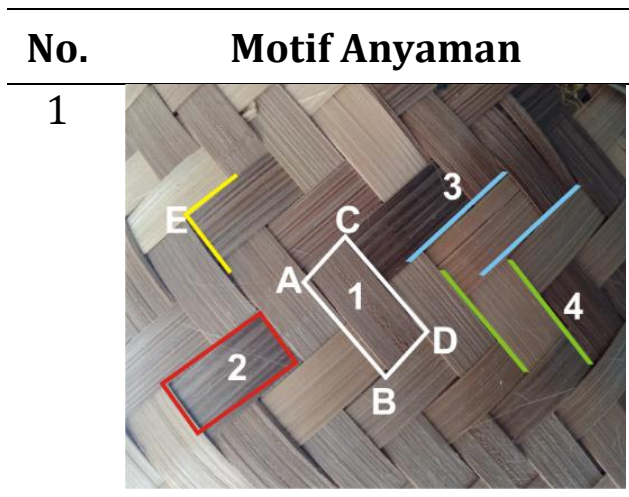

Identifikasi:

Motif anyaman pada tompo dan pot gantung

2

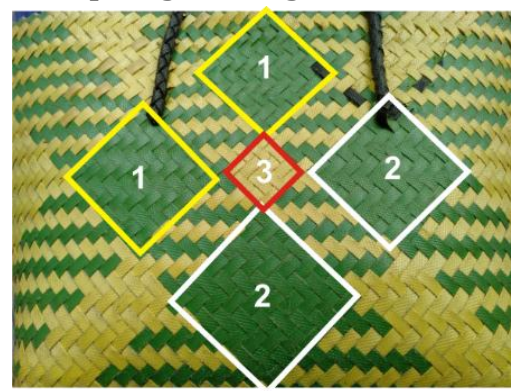

Identifikasi:

Motif anyaman pada tas

3

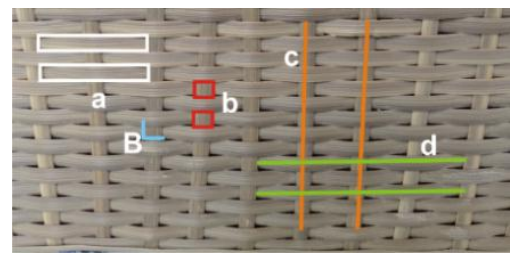

\section{Identifikasi:}

Motif anyaman pada tempat tissue dan pot bunga
Keterangan

Unsur matematika yang dapat ditemukan pada pola anyaman tompo diantaranya:

1. Bangun datar persegi panjang.

2. Sudut siku-siku.

3. Garis vertikal.

4. Garis horisontal.

5. Garis-garis yang saling sejajar.

6. Garis-garis yang saling tegak lurus.

7. Geometri transformasi pada bidang datar (rotasi dan translasi).

Unsur matematika yang dapat ditemukan pada pola anyaman tas diantaranya:

1. Bangun datar persegi dan belah ketupat.

2. Geometri transformasi pada bidang datar (refleksi, translasi, rotasi dan dilatasi).

Unsur matematika yang dapat ditemukan pada pola anyaman pada tempat tissue, pot bunga, dan pot gantung diantaranya:

1. Bangun datar persegi dan persegi panjang.

2. Sudut siku-siku.

3. Garis vertikal.

4. Garis horisontal.

5. Garis-garis yang saling sejajar.

6. Garis-garis yang saling tegak lurus.

7. Geometri transformasi pada bidang datar (translasi).

Konsep-konsep matematika yang dapat digali dan dipelajari dari motif anyaman Desa Plaosan antara lain sebagai berikut:

[1] Konsep matematika dalam motif anyaman tompo dan pot gantung

a) Bentuk dan ciri-ciri persegi panjang.

b) Jumlah dan model ruas garis yang membatasi persegi panjang.

c) Keliling persegi panjang.

d) Luas persegi panjang.

e) Jenis-jenis sudut (sudut lancip, sudut siku-siku, dan sudut tumpul). 
f) Menghitung besar sudut dengan menggunakan busur derajat.

g) Hubungan antar garis (garis yang saling sejajar, garis yang saling berhimpit, dan garis yang saling tegak lurus).

h) Hubungan antar sudut sebagai akibat dari dua garis sejajar yang dipotong oleh garis transversal.

i) Translasi (pergeseran).

j) Rotasi (perputaran).

[2] Konsep matematika dalam motif anyaman tas

a) Sifat-sifat persegi dan belah ketupat.

b) Keliling persegi dan belah ketupat.

c) Luas persegi dan belah ketupat.

d) Refleksi (pencerminan).

e) Translasi (pergeseran).

f) Rotasi (perputaran).

g) Dilatasi.

[3] Konsep matematika dalam motif anyaman pot bunga dan tempat tissue

a) Bentuk dan ciri-ciri persegi dan persegi panjang.

b) Jumlah dan model ruas garis yang membatasi persegi dan persegi panjang.

c) Keliling persegi dan persegi panjang.

d) Luas persegi dan persegi panjang.

e) Jenis-jenis sudut (sudut lancip, sudut siku-siku, dan sudut tumpul).

f) Menghitung besar sudut dengan menggunakan busur derajat.

g) Hubungan antar garis (garis yang saling sejajar, garis yang saling berhimpit, dan garis yang saling tegak lurus).

h) Hubungan antar sudut sebagai akibat dari dua garis sejajar yang dipotong oleh garis transversal.

i) Translasi (pergeseran).

Melalui uraian di atas, motif anyaman Desa Plaosan Kabupaten Kediri dapat digunakan sebagai bahan untuk menyusun perangkat dan media pembelajaran matematika berbasis budaya lokal. Guru dapat menyesuaikan dan mengemas materi pembelajaran dengan memanfaatkan unsur-unsur matematika yang ada dalam motif anyaman tersebut. Sebagai bahan acuan dan perbandingan, berikut diberikan tabel mengenai standar kompetensi dasar pembelajaran matematika di jenjang sekolah dasar dan menengah beserta produk anyaman yang dapat digunakan sebagai model untuk menyusun perangkat dan media pembelajaran: 
Tabel 2. Standar Kompetensi Dasar beserta Produk Anyaman yang Dapat Dimanfaatkan

\begin{tabular}{|c|c|c|}
\hline No. & Standar Kompetensi Dasar & Produk Anyaman \\
\hline 1 & $\begin{array}{l}\text { Matematika SD Kelas } 1 \text { Semester } 2 \text { Kurikulum 2013: } \\
\text { - Mengenal dan mengelompokkan bangun datar } \\
\text { melalui benda faktual. } \\
\text { - Mengidentifikasi jenis-jenis bangun datar yang } \\
\text { dapat membentuk pola pengubinan. } \\
\text { - Menyusun bangun-bangun datar untuk membentuk } \\
\text { pola pengubinan. }\end{array}$ & $\begin{array}{l}\text { Tompo, pot } \\
\text { gantung, pot } \\
\text { bunga dan tempat } \\
\text { tissue }\end{array}$ \\
\hline 2 & $\begin{array}{l}\text { Matematika SD Kelas } 1 \text { Semester } 2 \text { Kurikulum 2013: } \\
\text { - Menjelaskan dan merekognisi ruas garis melalui } \\
\text { model faktual bangun datar. } \\
\text { - Menjelaskan dan mengklasifikasikan bangun datar } \\
\text { berdasarkan ciri-cirinya. }\end{array}$ & $\begin{array}{l}\text { Tompo, pot } \\
\text { gantung, pot } \\
\text { bunga dan tempat } \\
\text { tissue }\end{array}$ \\
\hline 3 & $\begin{array}{l}\text { Matematika SD Kelas } 1 \text { Kurikulum 2013: } \\
\text { - Menjelaskan dan menentukan keliling bangun } \\
\text { datar. } \\
\text { - Menyelesaikan permasalahan yang berhubungan } \\
\text { dengan keliling bangun datar. } \\
\text { - Menjelaskan dan mengidentifikasi jenis sudut. }\end{array}$ & $\begin{array}{l}\text { Tompo, pot } \\
\text { gantung, pot } \\
\text { bunga dan tempat } \\
\text { tissue, tas }\end{array}$ \\
\hline 4 & $\begin{array}{l}\text { Matematika SD Kelas } 4 \text { Semester } 2 \text { Kurikulum 2013: } \\
\text { - Menjelaskan dan menentukan keliling serta luas } \\
\text { persegi panjang. } \\
\text { - Menyelesaikan permasalahan yang berhubungan } \\
\text { dengan keliling serta luas persegi panjang. } \\
\text { - Menjelaskan dan mengidentifikasi hubungan antar } \\
\text { garis dengan menggunakan benda faktual (garis } \\
\text { sejajar, berpotongan dan berhimpit). } \\
\text { - Menjelaskan dan menentukan ukuran sudut pada } \\
\text { suatu bidang datar dengan menggunakan busur } \\
\text { derajat. }\end{array}$ & $\begin{array}{l}\text { Tompo, pot } \\
\text { gantung, pot } \\
\text { bunga dan tempat } \\
\text { tissue }\end{array}$ \\
\hline 5 & $\begin{array}{l}\text { Matematika SMP Kelas } 7 \text { Semester } 2 \text { Kurikulum 2013: } \\
\text { - Menganalisis hubungan antar sudut sebagai akibat } \\
\text { dari dua garis sejajar yang dipotong oleh garis } \\
\text { transversal. } \\
\text { - Menyelesaikan masalah yang berkaitan dengan } \\
\text { hubungan antar sudut sebagai akibat dari dua garis } \\
\text { sejajar yang dipotong oleh garis transversal. }\end{array}$ & $\begin{array}{l}\text { Tompo, pot } \\
\text { gantung, pot } \\
\text { bunga dan tempat } \\
\text { tissue }\end{array}$ \\
\hline 6 & $\begin{array}{l}\text { Matematika SMP Kelas } 9 \text { Kurikulum 2013: } \\
\text { - Menjelaskan geometri transformasi yang } \\
\text { dihubungkan dengan masalah kontekstual. } \\
\text { - Menyelesaikan masalah kontekstual yang berkaitan } \\
\text { dengan geometri transformasi. }\end{array}$ & $\begin{array}{l}\text { Tompo, pot } \\
\text { gantung, pot } \\
\text { bunga dan tempat } \\
\text { tissue, tas }\end{array}$ \\
\hline
\end{tabular}


Analisis Aktifitas Fundamental Matematis menurut Bishop pada Kegiatan Menganyam di Desa Plaosan

Menurut Bishop (dalam Hartoyo, 2012) aktivitas manusia yang berhubungan dengan wujud budaya merupakan fenomena matematis yang dapat dikategorikan dalam enam kegiatan mendasar. Aktivitas tersebut meliputi kegiatan membilang, mengukur, mendesain, menentukan letak, menjelaskan, dan bermain. Hasil dari wawancara dan observasi aktivitas masyarakat Desa Plaosan dalam kegiatan menganyam, ditemukan enam aktifitas fundamental matematis sebagai berikut:

\section{Membilang}

Aktifitas membilang dilakukan oleh pengrajin anyaman bambu di Desa Plaosan ketika pengrajin tersebut menghitung banyaknya bambu yang akan dipotong dan dijadikan helaian. Satu potong bambu akan dijadikan 10 buah iratan dan setiap 1 iratan akan dijadikan 10-15 helaian dengan memperhatikan kondisi tebal atau tipisnya bambu. Aktifitas membilang juga ditemukan ketika para pengrajin menghitung harga bahan untuk produksi dan memperkirakan harga yang pas untuk penjualan setiap item produk agar tidak mengalami kerugian. Sebagai contoh, harga 1 bambu berkisar Rp 15.000,-. Dari 1 bambu ini akan dihasilkan sekitar 50 buah tompo ukuran kecil. Harga yang dipatok untuk 1 buah tompo kecil adalah Rp 2.500,-. Estimasi waktu pengerjaan 1 tompo kecil sekitar 15 menit.

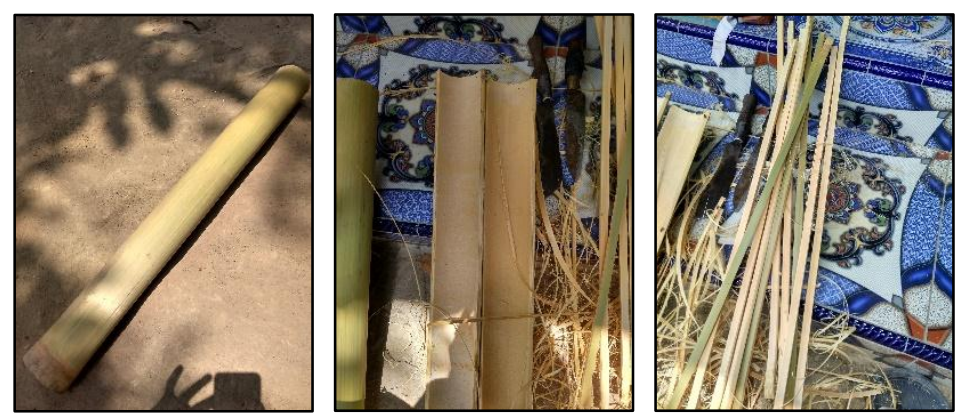

Gambar 6. Aktivitas membilang pada kegiatan menganyam di Desa Plaosan Sumber: Dokumentasi Peneliti

\section{Mengukur}

Aktifitas mengukur ditemukan saat para pengrajin anyaman akan memotong bambu. Alat ukur yang digunakan oleh para pengrajin ini adalah jari tangan orang dewasa dengan satuan jengkal. Satu jengkal didefinisikan sebagai jarak antara ujung ibu jari dan ujung jari tengah yang direntangkan secara penuh. Para pengrajin membagi ukuran potongan bambu dalam satuan rong jangkal (dua jengkal), telung jangkal (tiga jengkal), dan limang jangkal (lima jengkal). Untuk mengukur lebar iratan bambu, para pengrajin menggunakan acuan lebar jari telunjuk. 

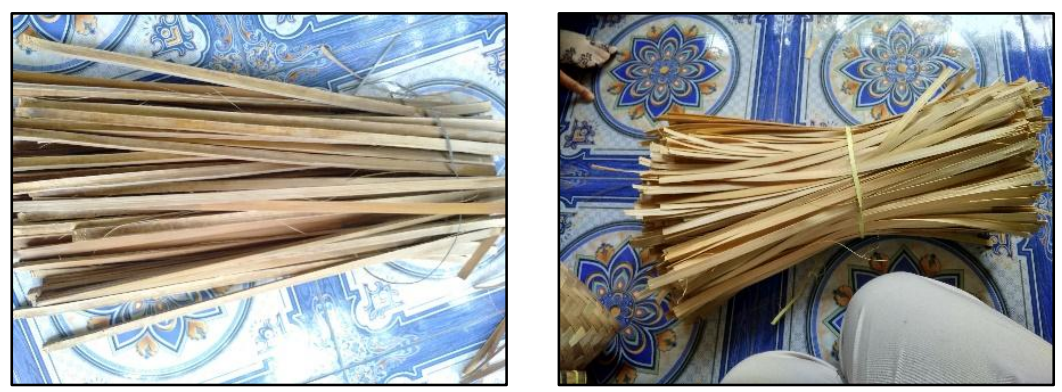

Gambar 7. Aktivitas mengukur pada kegiatan menganyam di Desa Plaosan Sumber: Dokumentasi Peneliti

\section{Mendesain}

Kegiatan mendesain dilakukan oleh para pengrajin ketika menyusun pola anyaman. Pola anyaman dibuat berbeda-beda dengan pertimbangan nilai ergonomis sekaligus untuk menambah nilai estetika. Sebagai contoh, pada bagian alas, pengrajin menganyam dengan pola anyaman wareg, pada bagian pojok alas, pengrajin menganyam dengan pola anyaman durno, sedangkan pada bagian selimut, pengrajin menganyam dengan pola anyaman kepang/kipas.
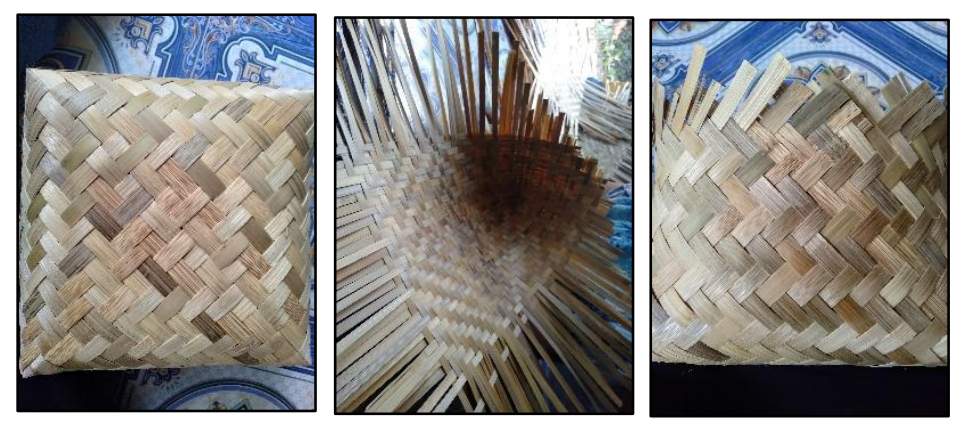

Gambar 8. Aktivitas mendesain pada kegiatan menganyam di Desa Plaosan Sumber: Dokumentasi Peneliti

\section{Menentukan Lokasi atau Letak}

Kegiatan menentukan letak dilakukan oleh pengrajin ketika harus meletakkan suatu pola di tempat yang benar. Pengrajin memulai tahap awal dengan melakukan anyam tunggal. Anyam tunggal didefinisikan sebagai anyaman dengan patokan satu helai bambu diletakkan melintang kemudian ditimpa dengan satu helai bambu yang diletakkan membujur. Setelah itu pengrajin melanjutkan dengan anyam dua. Anyam dua didefinisikan sebagai anyaman dengan patokan dua helai bambu diletakkan melintang kemudian ditimpa oleh dua helai bambu yang diletakkan membujur. 

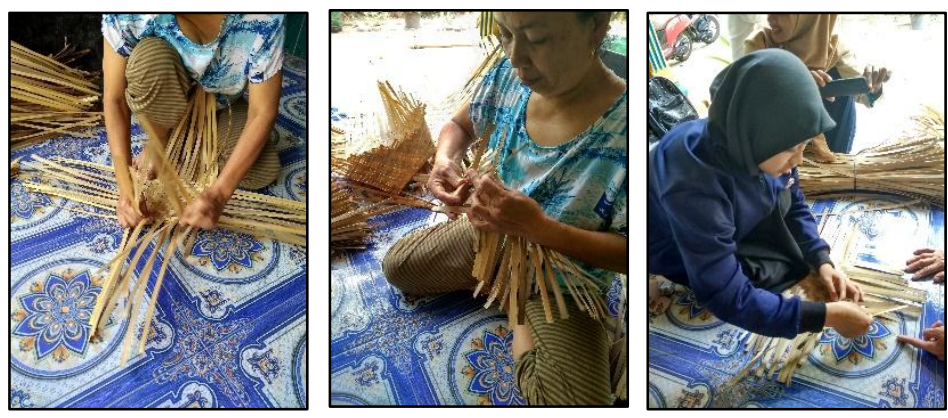

Gambar 9. Aktivitas menentukan letak pada kegiatan menganyam di Desa Plaosan Sumber: Dokumentasi Peneliti

\section{Bermain}

Kegiatan bermain yang dilakukan oleh para pengrajin adalah ketika membentuk motif saat anyam dua telah selesai dikerjakan. Para pengrajin memiliki teknik yang unik dalam menyusun dan membentuk motif serta memberikan warna pada motif. Pembentukan motif ini dilakukan untuk menambah tingkat kepuasan konsumen dan menambah nilai jual produk. Kegiatan bermain juga nampak ketika para pengrajin membuat siasat agar tetap bisa melakukan produksi di musim penghujan. Cara yang mereka lakukan adalah dengan menyimpan bambu kering sebagai persediaan bahan produksi di musim penghujan.
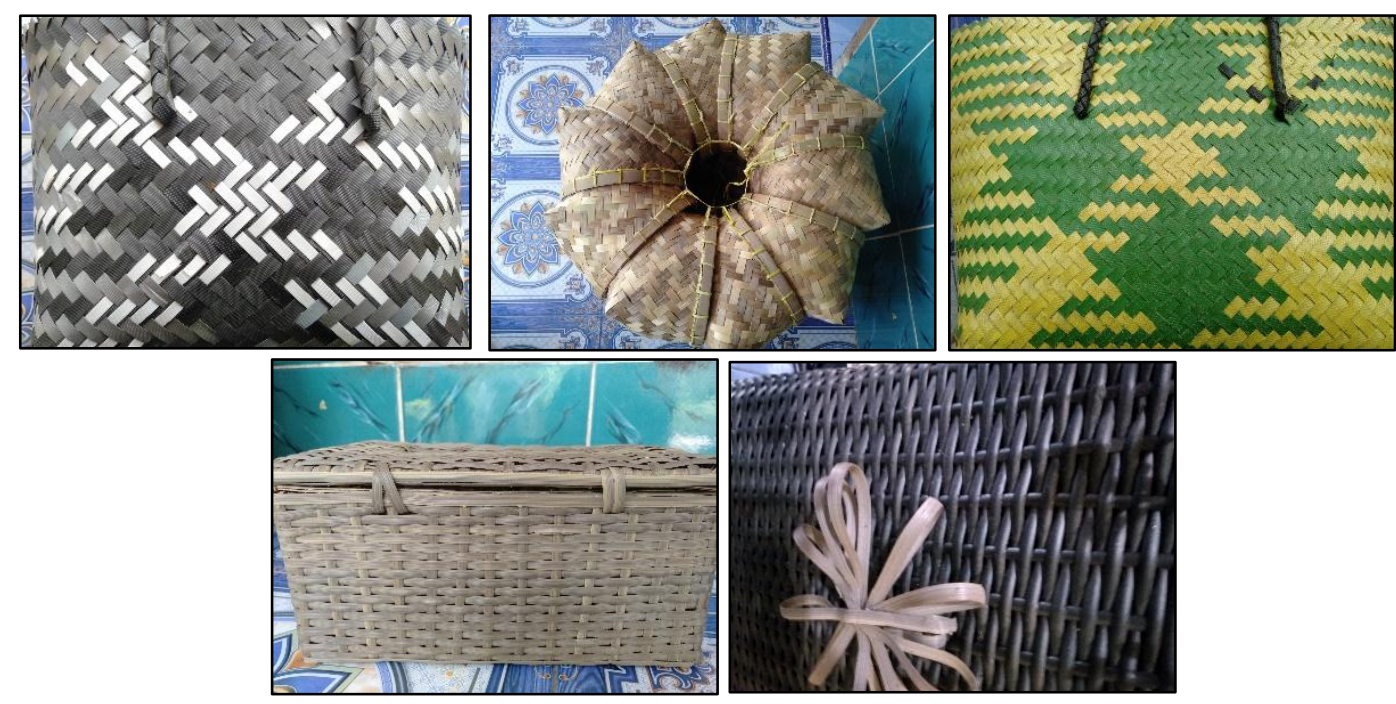

Gambar 10. Aktivitas membilang pada kegiatan menganyam di Desa Plaosan Sumber: Dokumentasi Peneliti

\section{Menjelaskan}

Aktivitas menjelaskan dilakukan oleh para pengrajin dengan menceritakan filosofi atau makna dari bentuk-bentuk khusus dari produk-produknya. Sebagai contoh, filosofi yang ada dalam produk tompo yang sama dengan filosofi boboko di daerah Sunda. Bentuk lingkaran pada bagian atas tompo memiliki arti manusia harus memiliki tekad yang kuat, sedangkan bagian bawah tompo yang berbentuk persegi memiliki filosofi manusia hidupnya harus teratur (Prabawati, 2016). 


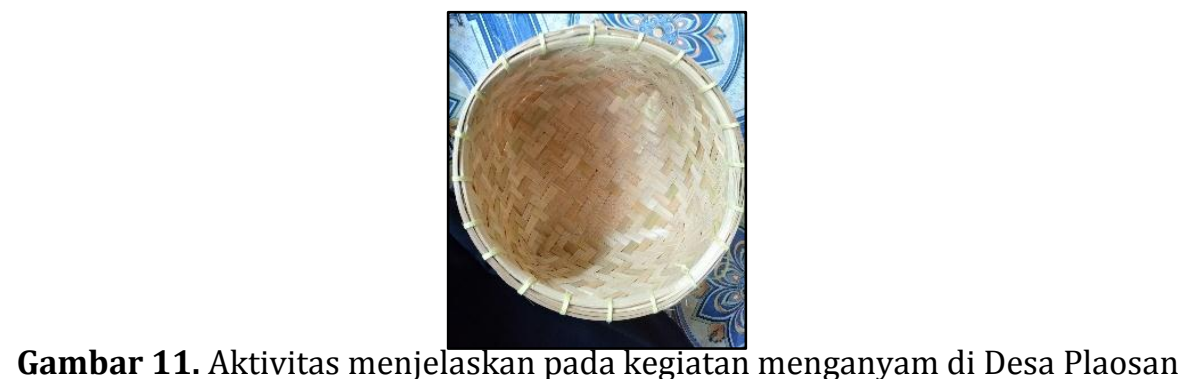

Gambar 11. Aktivitas menjelaskan pada kegiatan menganyam di Desa Plaosan Sumber: Dokumentasi Peneliti

\section{SIMPULAN}

Berdasarkan hasil pemaparan analisis data dapat disimpulkan bahwa terdapat etnomatematika dalam kerajinan anyaman Desa Plaosan Kabupaten Kediri. Beberapa unsur matematis yang dapat ditemukan dalam motif anyaman produk kerajian anyaman Desa Plaosan diantaranya, konsep mengenai bidang datar, konsep mengenai garis dan hubungan antar garis, konsep mengenai sudut, dan konsep mengenai geometri transformasi. Adapun aktifitas fundamental matematis menurut Bishop yang dapat ditemukan dalam kegiatan menganyam di Desa Plaosan sejumlah 6 kegiatan meliputi aktifitas membilang, menghitung, mendesain, menentukan letak, bermain dan menjelaskan. Etnomatematika yang ada dalam pola anyaman ini dapat digunakan sebagai salah satu bahan pembelajaran di jenjang sekolah dasar dan sekolah menengah.

\section{REFERENSI}

Anggraena, Y. (2019). Pengembangan Kurikulum Matematika untuk Meningkatkan Kemampuan Siswa Dalam Penalaran dan Pemecahan Masalah. Alifmatika: Jurnal Pendidikan dan Pembelajaran Matematika, 1(1), 15-27. https://doi.org/10.35316/alifmatika.2019.v1i1.15-27

d'Entremont, Y. (2015). Linking Mathematics, Culture and Community. Procedia Social and Behavioral Sciences, 174(1999), 2818-2824. https://doi.org/10.1016/j.sbspro.2015.01.973

Gafoor, A., \& Kurukkan, A. (2015). Why High School Students Feel Mathematics Difficult? An Exploration of Affective Beliefs. Conference Paper, August 2016, 23-27. https://doi.org/10.13140/RG.2.2.18880.12800

Hartoyo, A. (2012). Eksplorasi Etnomatematika pada Budaya Masyarakat Dayak Perbatasan Indonesia-Malaysia Kabupaten Sanggau Kalbar. Jurnal Penelitian Pendidikan, 13(1), 14-23. http://jurnal.upi.edu/penelitianpendidikan/view/1387/eksplorasi-etnomatematika-pada-budayamasyarakat-dayak-perbatasan-indonesia-malaysia-kabupaten-sanggaukalbar-.html

Ilmiyah, N. F., Rofiqoh, I., Mufti, R., Sholihah, N., Studi, P., \& Matematika, T. (2020). Analisis Etnomatematika dalam Seni Ornamen dan Rancang Bangun Masjid Al-Khalid Kediri Sebagai Pengembangan Pembelajaran Matematika Berbasis Budaya. Prosiding Seminar Nasional Pendidikan Dan Ilmu Matematika (SENANDIKA), "Gerak Lincah Pembelajaran Matematika di Era Inteligensi Semu," 332-341. 
Jannah, H. N. (2019). Etnomatematika: Batik Khas Kediri Sebagai Media Pembelajaran Matematika Barisan dan Deret Aritmetika. Prosiding SEMDIKJAR (Seminar Nasional Pendidikan Dan Pembelajaran), 3, 440-446. http://ojs.semdikjar.fkip.unpkediri.ac.id/index.php/SEMDIKJAR/article/view $/ 48$

Khalimah, N., Farin, K. I., Nikmah, M., Ni'mah, K., \& Jatmiko, J. (2017). Budaya Kediri dalam Pembelajaran Matematika (Pengembangan Lembar Kegiatan Siswa (LKS) Berbasis Etnomatematika Melalui Pendekatan Saintifik). JIPMat, 2(1), 65-71. https://doi.org/10.26877/jipmat.v2i1.1482

Prabawati, M. N. (2016). Etnomatematika Masyarakat Pengrajin Anyaman Rajapolah Kabupaten Tasikmalaya. Infinity Journal, 5(1), 25. https://doi.org/10.22460/infinity.v5i1.p25-31

Puspadewi, K. R., \& Putra, I. G. N. N. (2014). Etnomatematika di Balik Kerajinan Anyaman Bali. Matematika, 4(2), 80-89.

Ratuanik, M., \& Kundre, O. T. (2018). Pemanfaatan Etnomatematika Kerajinan Tangan Anyaman Masyarakat Maluku Tenggara Barat dalam Pembelajaran. Prosiding Seminar Nasional Etnomatnesia, 416-423.

Resfaty, A. G., Muzdalipah, I., \& Hidayat, E. (2019). Studi Etnomatematika: Mengungkap Gagasan dan Pola Geometris pada Kerajinan Anyaman Mendong di Manonjaya Kabupaten Tasikmalaya. Journal of Authentic Research on Mathematics Education (JARME), 1(1), 19-26.

Rosa, M., \& Orey, D. C. (2011). Ethnomathematics: Aspek Budaya Matematika Etnomatemática: os Aspectos Culturais da Matematica. Revista Latinoamericana de Etnoatematica, 4(2), 32-54.

Samijo, S., \& Yohanie, D. D. (2017). Pengaruh Model Pembelajaran Kontekstual Berbasis Etnomatematika Pada Pola Batik Tenun (ATBM) Khas Kota Kediri Terhadap Kemampuan Refleksi dan Simetri Mahasiswa Semester 2 Prodi Pendidikan Matematika UNP Kediri. Jurnal Math Educator Nusantara: Wahana Publikasi Karya Tulis Ilmiah Di Bidang Pendidikan Matematika, 3(2), 135. https://doi.org/10.29407/jmen.v3i2.11975

Soedjadi, R. (2007). Masalah Konstektual sebagai Batu Sendi Matematika Sekolah. Pusat Sains dan Matematika Sekolah UNESA.

Wahyuni, A., Aji, A., Tias, W., \& Sani, B. (2013). P - 15 Peran Etnomatematika dalam Membangun Karakter Bangsa. Prosiding Seminar Nasional Matematika Dan Pendidikan Matematika FMIPA UNY, November, 978-979. 